\title{
GOSPODARCZE I SPOŁECZNE ZNACZENIE ZWIERZĄT NIEUDOMOWIONYCH DLA SPOŁECZNOŚCI WCZESNONEOLITYCZNYCH W WYBRANYCH REJONACH EUROPY ŚRODKOWEJ
}

\author{
ECONOMIC AND SOCIAL IMPORTANCE \\ OF NON-DOMESTICATED ANIMALS TO THE \\ EARLY-NEOLITHIC COMMUNITIES IN CENTRAL EUROPE
}

\author{
Beata Honkisz
}

Instytut Prahistorii, Uniwersytet im. Adama Mickiewicza ul. Św. Marcin 78, 61-809 Poznań, Poland

\begin{abstract}
This article is a shortened version of the author's MA thesis, which was presented in 2011. It has been also an attempt to present the most important aspects of the importance of non-domestic animals for the Linear Pottery culture communities inhabiting Central Europe in the early Neolithic. For this purpose, the analysis was carried out within a selected trial area, from where the material was collected. It included three regions, where intensified settlement of the Linear Pottery communities took place in the early Neolithic: the Elbe and Saale river basin, Małopolska (also referred to as Lesser Poland) and Kujawy (Kuiavia). In the trial area fourteen sites were located and then analysed for the presence of remains of domestic animals.
\end{abstract}

\section{ZARYS PROBLEMATYKI}

Problematyka znaczenia zwierząt dzikich w gospodarce pierwszych neolitycznych rolników zasiedlających tereny Europy Środkowej była do tej pory sygnalizowana jedynie przy okazji syntetycznych opracowań dotyczących całości gospodarki neolitycznej. Celem artykułu jest próba rozpoznania znaczenia zwierząt dzikich dla społeczności wczesnorolniczych $\mathrm{w}$ aspekcie gospodarczym i społecznym ${ }^{1}$. Pierwszy aspekt jest rozumiany jako wszelka działalność człowieka prowadząca do zdobycia pożywienia, wyboru miejsca osiedlenia się, budowy obiektów mieszkalnych oraz sze-

${ }^{1}$ Artykuł stanowi skróconą wersję mojej pracy magisterskiej, która powstała w Instytucie Prahistorii UAM pod kierownictwem Profesora Arkadiusza Marciniaka (Honkisz 2011). 
roko pojęta technologia (wytwarzanie dóbr, a także, w następnych etapach, ich dystrybucja oraz konsumpcja). Aspekt społeczny oznacza pozautylitarne znaczenie zwierząt nieudomowionych oraz sposoby ich postrzegania przez pierwszych rolników ${ }^{2}$.

W toku realizacji celów pracy zostanie przeprowadzona analiza opracowań materiałów kostnych ze stanowisk neolitycznych na badanym obszarze ${ }^{3}$. Oprócz metod tradycyjnie stosowanych $\mathrm{w}$ archeozoologii, takich jak identyfikacja gatunkowa, przeprowadzona zostanie także analiza anatomiczna w celu określenia charakteru konsumpcji. Otrzymane wyniki analiz archeozoologicznych odniesione zostaną do kontekstów, w których zarejestrowano zwierzęce szczątki kostne.

Analiza gospodarczego i społecznego znaczenia zwierząt nieudomowionych zostanie przeprowadzona dla wczesnego neolitu z obszaru Europy Środkowej. Bazę źródłową stanowią szczątki kostne pochodzące ze stanowisk kultury ceramiki wstęgowej rytej, a także późnej ceramiki wstęgowej. Kryterium doboru materiałów nie ogranicza się jedynie do tradycyjnie pojmowanej systematyki kulturowej, bardziej zasadne wydaje się odniesienie tych zagadnień do ważnego zjawiska, jakim jest kolonizacja Europy Środkowej przez pierwszych rolników przybyłych z obszarów naddunajskich ${ }^{4}$, a następnie ugruntowanie się wzorców osadniczych tych grup na nowym terenie ${ }^{5}$. Warto zwrócić w tym miejscu uwagę na ważny element: pojawienie się nowej grupy ludności z charakterystycznym pakietem kultury materialnej oraz odmiennym modelem gospodarczym ${ }^{6}$.

Całościowy przegląd wszystkich stanowisk wczesnoneolitycznych znajdujących się w Europie Środkowej jest tutaj, ze względu na brak miejsca, niemożliwy. Stąd też zakres przestrzenny niniejszej pracy ograniczać się będzie do obszaru próbnego, z którego zostały wybrane stanowiska poddane analizie wedle określonych powyżej kryteriów (por. ryc. 1). Punktem wyjścia w przyjętej procedurze badawczej jest wykonanie analizy porównawczej szczątków zwierzęcych pozyskanych ze stanowisk z przestrzennie zwartych rejonów, niestanowiących tym samym przypadkowego zbioru punktów rozrzuconych na mapie. Stan zachowania kości w interesującym nas okresie jest ściśle związany z rodzajem gleb występujących na danym obszarze. Biorąc pod uwagę preferencję osiedlania się ludności wczesnorolniczej na glebach lessowych, które nie sprzyjają zachowaniu się materiału kostnego $^{7}$, należy liczyć się ze znaczną utratą informacji $^{8}$ o gospodarce zwierzętami. Stąd też dla wielu stanowisk wczesno-

\footnotetext{
${ }^{2}$ Por. Cummings, Harris 2011.

${ }^{3}$ Döhle 1994; Grygiel 2004. Informacje o materiale kostnym z większości stanowisk pochodzą natomiast $\mathrm{z}$ bazy danych udostępnionej mi przez Profesora Arkadiusza Marciniaka.

${ }^{4}$ Proces ten dokonywał się na poziomie kultury ceramiki wstęgowej rytej, zwłaszcza jej wczesnych faz.

${ }^{5}$ Zjawisko to jest czytelne w młodszych fazach kultury ceramiki wstęgowej rytej oraz w kulturze późnej ceramiki wstęgowej.

${ }^{6}$ Por. np. Czerniak 1994.

${ }^{7}$ Na przykład południowa Polska czy dorzecze górnego Renu (por. np. Bogucki, Grygiel 1981, 1993).

${ }^{8}$ Należy pamiętać, iż owa utrata informacji następuje także na skutek niemożliwości oznaczenia przynależności gatunkowej części szczątków kostnych. W niniejszym artykule zostały więc one pominięte.
} 
neolitycznych nie dysponujemy danymi archeozoologicznymi, mimo iż są one bogato reprezentowane pod względem archeologicznym. Stanowiska kultur wstęgowych, na których materiał kostny nie uległ zniszczeniu, stanowią mniejszość ${ }^{9}$. Kierując się tymi zasadami, wyodrębniono trzy rejony, z których pochodzą stanowiska poddane analizie w niniejszej pracy.

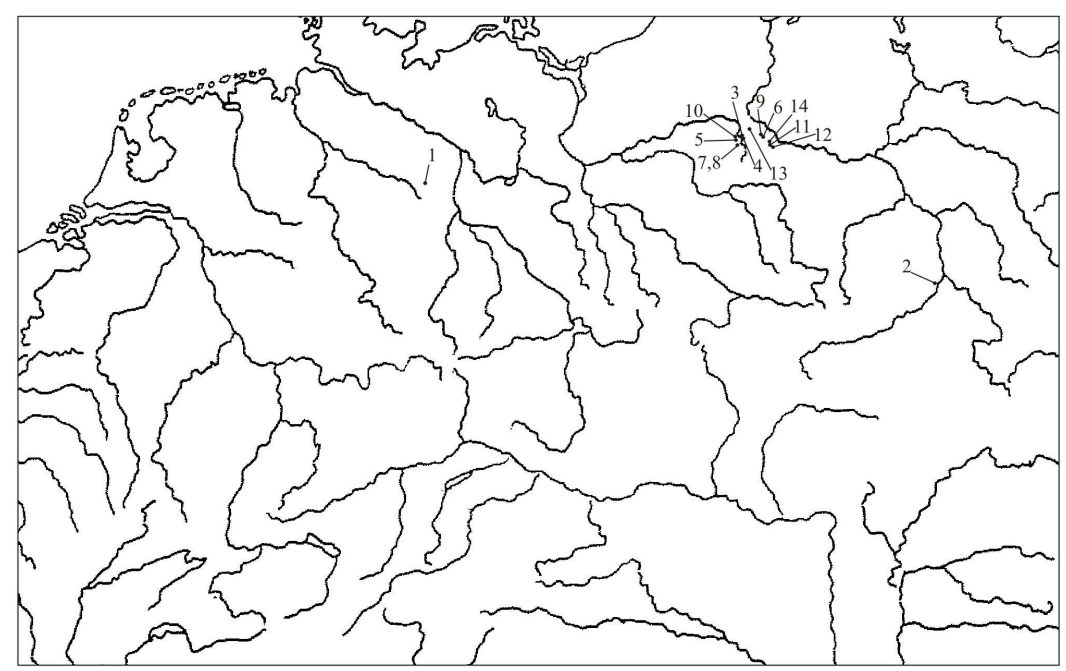

Ryc. 1. Rozmieszczenie stanowisk ujętych w artykule: 1 - Eilsleben; 2 - Samborzec; 3 - Miechowice 7; 4 - Łojewo 35; 5 - Bożejewice 22/23; 6 - Siniarzewo 1; 7 - Żegotki 2; 8 - Żegotki 3; 9 - Kuczkowo 5; 10 - Węgierce 12; 11 - Brześć Kujawski 4; 12 - Smólsk 4; 13 - Zagajewice 1; 14 - Wolica Nowa 1

Fig. 1. Location of the sites: 1 - Eilsleben; 2 - Samborzec; 3 - Miechowice 7; 4 - Łojewo 35; 5 - Bożejewice 22/23; 6 - Siniarzewo 1; 7 - Żegotki 2; 8 - Żegotki 3; 9 - Kuczkowo 5; 10 - Węgierce 12; 11 - Brześć Kujawski 4; 12 - Smólsk 4; 13 - Zagajewice 1; 14 - Wolica Nowa 1

\section{Kujawy}

$\mathrm{Z}$ tego rejonu pochodzi najwięcej analizowanych w pracy stanowisk. Ze względu na dużą jednorodność i zwarte osadnictwo lokowane na sprzyjających zachowaniu się szczątków kostnych czarnoziemach, będzie on miał charakter reperowy, do którego odnosić się będą ustalenia z pozostałych terenów. Najstarsze materiały wstęgowe z terenu Kujaw datowane są na ok. 5390-5370 BC, a więc nie odbiegają pod względem chronologicznym od znalezisk $\mathrm{z}$ południowej Polski ${ }^{10}$. Na potrzeby analizy uwzględniającej obecność szczątków zwierząt dzikich wybranych zostało trzynaście

\footnotetext{
${ }^{9}$ Dotyczy to przede wszystkim terenów pokrytych czarnymi ziemiami (np. Kujaw - por. np. Bogucki, Grygiel 1986).

${ }^{10}$ Kulczycka-Leciejewiczowa 2008, 103-110.
} 
stanowisk kujawskich. Pochodzą one z osad kultury ceramiki wstęgowej rytej (Miechowice 7, Łojewo 35, Bożejewice 22/23, Żegotki 2, Brześć Kujawski 4, Smólsk 4, Zagajewice 1, Wolica Nowa 1), kultury późnej ceramiki wstęgowej (Żegotki 3, Kuczkowo 5, Węgierce 12, Radojewice 29), a także z osady, na której zarejestrowano pozostałości obu tych kultur (Siniarzewo 1). Część z nich została przebadana ratowniczo przy okazji budowy gazociągu jamalskiego (Żegotki 2 i 3, Kuczkowo 5, Radojewice 29, Bożejewice 22/23, Siniarzewo 1). Należy w tym miejscu zaznaczyć, iż możliwości poznawcze dotyczące tych stanowisk są ograniczone, gdyż w większości przypadków odsłonięty został pas ziemi o szerokości jedenastu metrów, co pozwoliło na uchwycenie jedynie fragmentów osad. O poszerzeniu wykopu zdecydowano w Bożejewicach, gdzie zarejestrowano pozostałości długiego domu o długości około 43 metrów. Wzdłuż niego ciągnęły się glinianki, które po wydobyciu z nich gliny miały przejmować funkcje pracowni krzemieniarskich, a w końcu jam odpadkowych ${ }^{11}$, gdzie deponowane były również pozostałości pokonsumpcyjne, w tym zwierzęce szczątki kostne. Tę prawidłowość można zaobserwować na pozostałych stanowiskach kujawskich. Na ślady konstrukcji słupowych natrafiono także na stanowisku Radojewice 29 , jednak w tym przypadku odkryty został jedynie fragment domostwa, więc nie jest znana jego całkowita długość. Jego szerokość wynosiła około 6 metrów ${ }^{12}$.

Osobną grupę stanowią tu także cztery stanowiska położone w rejonie Brześcia Kujawskiego i Osłonek (Brześć Kujawski 4, Smólsk 4, Zagajewice 1, Wolica Nowa 1), stanowiące zwarty mikroregion osadniczy ${ }^{13}$. Widoczne są tutaj również ślady zabudowy słupowej. W Zagajewicach zarejestrowano jeden nieduży budynek ${ }^{14}$. W Wolicy Nowej odkryto pozostałości dwóch obiektów mieszkalnych, natomiast w Brześciu Kujawskim - pozostałości po trzech długich domach, przy czym najwięcej materiału ruchomego dostarczyły obiekty położone w bliskim sąsiedztwie owych budowli ${ }^{15}$. Bezpośrednich pozostałości zabudowy słupowej nie stwierdzono natomiast w Smólsku, jednak ułożenie jam gliniankowych sugerowało, iż puste przestrzenie między nimi mogły być w przeszłości zajmowane przez długie domy ${ }^{16}$.

Pozostałości po zabudowie słupowej są także czytelne w Łojewie - odsłonięto tutaj zarys jednego długiego domu o konstrukcji słupowej wraz z towarzyszącymi mu obiektami ${ }^{17}$. Obiekt mieszkalny ze stanowiska Miechowice 7 został natomiast określony jako ziemianka ${ }^{18}$. Na stanowisku Węgierce 12 odsłonięto jedynie fragment budowli mieszkalnej, gdyż nie został przebadany cały teren osady ${ }^{19}$.

\footnotetext{
${ }^{11}$ Czerniak 1998.

${ }^{12}$ Pyzel 2010, tab. 37

${ }^{13}$ Por. Grygiel 2004.

${ }^{14}$ Grygiel 2004, 448.

${ }^{15}$ Grygiel 2004, 183.

${ }^{16}$ Grygiel 2004, 258.

${ }^{17}$ Czerniak 1994, Szmyt 1992.

${ }^{18}$ Nadolna 2001, 14.

${ }^{19}$ Czerniak 1992.
} 


\section{Małopolska}

Obszar ten charakteryzuje się występowaniem dużych, zwartych osad wstęgowych. W związku z tym, iż obecne tu gleby lessowe nie sprzyjają zachowaniu szczątków organicznych, w tym kości zwierzęcych, rejon ów będzie w niniejszym artykule reprezentowany tylko przez jedno stanowisko - osadę w Samborcu. Ślady osadnictwa wczesnorolniczego są tutaj przemieszane z późniejszymi (głównie eneolitycznymi i wczesnobrązowymi), co stanowi pewne utrudnienie dla badacza. Mimo to udało się wyodrębnić obiekty „,czystej” kultury ceramiki wstęgowej rytej, podzielonej na trzy fazy chronologiczne. Warto podkreślić, iż na omawianym stanowisku nie zostały zarejestrowane pozostałości po zabudowie słupowej w postaci dołków posłupowych, a jedynie glinianki i różnego rodzaju jamy odpadkowe, z których pochodzi materiał kostny. Sytuacja taka mogła być wynikiem działania procesów denudacyjnych o charakterze antropogenicznym, które powodowały osuwanie górnych warstw ziemi, a wraz z nimi płytszych obiektów (dołki posłupowe). Dowodem na potwierdzenie tych przypuszczeń może być obecność pustych miejsc pomiędzy obiektami określanymi jako glinianki ${ }^{20}$.

\section{Dorzecze Łaby i Soławy}

Jedna z najstarszych dat z Saksonii i Turyngii pochodzi z osady w Eitzum 5180-5380 $\pm 100 \mathrm{BC}^{21}$. Pod względem obecności szczątków zwierzęcych sytuacja wygląda tutaj podobnie jak na terenie Małopolski - brakuje dobrze zachowanych serii kostnych z omawianego okresu. Wyjątek stanowi osada obronna w Eilsleben, rozmiarami kilkukrotnie przekraczająca stanowiska kujawskie. Podczas badań zarejestrowano liczne obiekty o charakterze osadniczym, z których część została określona jako miejsca składowania odpadków pokonsumpcyjnych, głównie na podstawie obecności w nich silnie rozdrobnionych kości zwierzęcych, noszących ślady cięcia oraz rąbania. Drugim typem obiektów zawierających szczątki zwierzęce są glinianki, wielowarstwowe obiekty ciągnące się wzdłuż ścian domostw. Gdy przestawały pełnić swoją funkcję, również były zasypywane odpadkami pokonsumpcyjnymi. Ważnym elementem architektonicznym są pozostałości po ogrodzeniu w postaci rowu, z którego także pochodzą liczne szczątki zwierzęce. Na początku prac badawczych wykonano wkopy sondażowe $w$ trzech jego miejscach. Przekroje otrzymanych profili rozstrzygnęły o przypisaniu mu funkcji obronnej - były one typowe dla osad umocnionych, miały nieckowaty kształt, ich szerokość górna wynosiła około sześciu metrów. Wzdłuż rowu, po jego wewnętrznej stronie, biegła najprawdopodobniej palisada ${ }^{22}$.

\footnotetext{
${ }^{20}$ Kulczycka-Leciejewiczowa 2008, 64.

${ }^{21}$ Niquet 1963, 1966 (cyt. za: Schwarz-Mackensen 1983, 28).

${ }^{22}$ Kaufmann 1977, 95.
} 


\section{KRYTERIA DOBORU MATERIALU I METODY BADANIA ZWIERZĘCYCH SZCZĄTKÓW KOSTNYCH}

Dobór źródeł został przeprowadzony według ściśle określonych kryteriów. Przedmiotem zainteresowania były materiały o niebudzącej wątpliwości atrybucji kulturowej. Odrzucone zostały kości zwierzęce znajdujące się w warstwie ornej lub na złożu wtórnym, gdyż nie jest możliwe określenie ich chronologii. W praktyce zatem znaczenie będą mieć jedynie szczątki pochodzące z obiektów, w których występują inne materiały (głównie ceramika), pozwalające stwierdzić przynależność kulturową kości zwierzęcych.

Analiza znaczenia nieudomowionych zwierząt przebiegać będzie na kilku płaszczyznach. Punktem wyjścia jest analiza archeozoologiczna szczątków zwierzęcych występujących w danym obiekcie, następnie ich współwystępowanie z innymi zabytkami ruchomymi, a w dalszej kolejności próba określenia przestrzennej dystrybucji kości zwierząt dzikich na stanowisku - relacji obiektów zawierających je do obiektów pozbawionych kości. Ostatnim etapem interpretacji jest porównanie ze sobą stanowisk w obrębie poszczególnych rejonów (Kujawy), a wreszcie porównanie ze sobą trzech wybranych rejonów osadniczych (Kujawy, Małopolska, dorzecze Łaby i Soławy). Zarysowana czterostopniowa procedura badawcza (obiekt - stanowisko - grupa stanowisk - rejony osadnicze) dotyczy przestrzennego wymiaru rozważań. Badanie znaczenia zwierząt nieudomowionych będzie także przebiegać na płaszczyźnie uwzględniającej przemiany chronologiczne. W tym celu cały materiał został podzielony na dwie fazy: kulturę ceramiki wstęgowej rytej i kulturę późnej ceramiki wstęgowej. Obie te jednostki występują na wybranych obszarach, nierzadko w obrębie pojedynczej osady (Siniarzewo 1), lub na osiedlach bezpośrednio ze sobą graniczących (Żegotki 2 i 3). Podział ten ma na celu uchwycenie ewentualnych przemian zachodzących w czasie, wraz z postępem zasiedlenia nowych terenów przez ludność o tradycji naddunajskiej.

\section{Podstawowe metody analizy materiałów faunistycznych}

Pojęcie zwierząt dzikich odnosi się do wszystkich dziko żyjących gatunków ${ }^{23}$. Przynależność ta nie budzi wątpliwości w przypadku gatunków, które nigdy nie zostały udomowione przez człowieka, takich jak jeleń (Cervus elaphus) czy sarna (Capreolus capreolus). Dość dużą natomiast trudność sprawia rozróżnienie form obecnych na interesującym nas terenie w środowisku naturalnym, które występują również jako zwierzęta domowe. Chodzi tu głównie o problemy, jakich nastręcza rozróżnienie bydła domowego (Bos taurus) od formy dzikiej (tur - Bos primigenius), gdyż żaden z tych taksonów nie ma wyraźnych cech dystynktywnych. Podzia-

\footnotetext{
${ }^{23}$ Zamiennie można tu również używać określenia „,zwierzęta łowne”, odnoszącego się do gatunków, które były we wczesnym neolicie przedmiotem polowań.
} 
łu dokonuje się jedynie na podstawie cech metrycznych (wielkości kości) ${ }^{24}$. U tura są one przeważnie większe, silniej jest także zaznaczony dymorfizm płciowy. Kolejnym utrudnieniem jest podobieństwo tura do żubra (Bison bonasus), które dotyczy zwłaszcza szkieletu postkranialnego ${ }^{25}$. Sytuacja wygląda podobnie przy próbie odróżnienia dzika (Sus scrofa) od świni (Sus scrofa f. domestica). Również w tym przypadku decydująca jest wielkość szkieletu, który osiąga mniejsze rozmiary $\mathrm{u}$ form domowych. W niniejszym artykule zostały wzięte pod uwagę jedynie te kości, których przynależność gatunkowa nie budzi wątpliwości.

Osobną grupę stanowią gatunki, które zostały udomowione przez człowieka w okresie późniejszym, na etapie wczesnego neolitu pozostające jeszcze formami dzikimi - chodzi tu głównie o konia (Equus ferus). W literaturze panuje obecnie przekonanie, iż w omawianym okresie był on zwierzęciem nieudomowionym ${ }^{26}$.

Jak już wspominiano, analiza szczątków zwierząt dzikich będzie obejmować cztery etapy. Podczas szacowania liczby kości interesujących nas gatunków wykorzystana została metoda zliczania całkowitej liczby fragmentów kostnych, należących do danego taksonu (NISP - Number of Identified Species), przy czym, jeżeli jedna kość była podzielona na kilka fragmentów, potraktowano je jako przynależące do tej jednej kości, i policzone jako pojedynczy element ${ }^{27}$.

\section{Metody analizy kontekstowej materiałów faunistycznych}

Pod pojęciem kontekstu rozumiane są tutaj wszystkie przedmioty, które występują w pewnej relacji do badanego przeze mnie przedmiotu (szczątków zwierząt dzikich), a więc tworzą całość jego istotnego otoczenia ${ }^{28}$. W niniejszym artykule definicja ta odnosić się będzie zarówno do samego stanowiska, na którym występują interesujące nas materiały, jak i do rodzaju obiektów, w których występują, oraz innych kategorii zabytków ruchomych. Warto zaznaczyć, iż w celu ustalenia wzajemnych proporcji także szczątki zwierząt domowych zostały zaliczone do kontekstu.

\section{ANALIZA MATERIALU EMPIRYCZNEGO}

\section{Kujawy}

Stanowiska $\mathrm{z}$ tego rejonu charakteryzują się relatywnie dobrym stanem zachowania kości zwierzęcych, które są jednak bardzo rozdrobnione. Odsetek zwierząt

\footnotetext{
${ }^{24}$ Döhle 1994.

${ }^{25}$ Becker, Johansson 1981 (cyt. za: Döhle 1994).

${ }^{26}$ Mallory, Douglas 1997.

${ }^{27}$ Np. Chaplin 1971; Grayson 1984; Klein, Cruz-Uribe 1984 (cyt. za: Marciniak 1996, 75).

${ }^{28}$ Hodder 1995, 174.
} 
łownych przedstawiał się podobnie na większości stanowisk i był niewielki: mieścił się $\mathrm{w}$ przedziale od zaledwie $0,6 \% \mathrm{w}$ Radojewicach do $5,5 \%$ na stanowisku 4 w Smólsku. Zupełnie wyjątkowo na tym tle przedstawia się stanowisko Wolica Nowa, na którym udział zwierząt łownych wyniósł aż 14\% (por. tab. 1). Odsetek ten został jednak znacznie zawyżony przez liczne szczątki ryb (Pisces), które stanowiły ponad 1/4 wszystkich gatunków łownych, a także żółwia błotnego (Emys orbicularis). Sytuacja taka może być jednak spowodowana nie tyle odbiciem stanu faktycznego (zwiększoną konsumpcją tzw. fauny wodnej przez mieszkańców osady), ile zastosowaniem odmiennych technik wykopaliskowych (płukanie wypełnisk obiektów), co

Tabela 1. Relacje ilościowe między gatunkami łownymi $(\mathrm{n}=1065)$ a domowymi $(\mathrm{n}=16866)$ na poszczególnych stanowiskach ujętych $w$ analizie

Table 1. Quantity ratio of game $(n=1065)$ and domestic species $(n=16866)$ at particular analysed sites

\begin{tabular}{|c|c|c|c|}
\hline Stanowisko & $\begin{array}{c}\text { Całkowita liczba } \\
\text { kości - wszystkie } \\
\text { obiekty }\end{array}$ & $\begin{array}{c}\text { Liczba kości } \\
\text { zwierząt dzikich }\end{array}$ & $\begin{array}{c}\text { Udział kości } \\
\text { zwierzạt dzikich } \\
(\%)\end{array}$ \\
\hline Eilsleben, starsza KCWR & 1371 & 123 & 8,9 \\
\hline Eilsleben, młodsza KCWR & 1042 & 79 & 7,5 \\
\hline Eilsleben KCWR & 1982 & 291 & 14,6 \\
\hline Eilsleben - całość & 4395 & 493 & 11,2 \\
\hline Samborzec, wczesna faza & 67 & 3 & 4,4 \\
\hline Samborzec, środkowa faza & 224 & 21 & 9,3 \\
\hline Samborzec, późna faza & 153 & 22 & 14,3 \\
\hline Samborzec - całość & 444 & 46 & 10,3 \\
\hline Miechowice 7, KCWR & 1457 & 52 & 3,5 \\
\hline Łojewo 35, KCWR & 1305 & 43 & 3,1 \\
\hline Bożejewice 22, KCWR & 2389 & 52 & 2,1 \\
\hline Radojewice 29, KCWR & 822 & 5 & 0,6 \\
\hline Siniarzewo 1, KCWR & 207 & 7 & 3,3 \\
\hline Siniarzewo 1, KPCW & 1114 & 52 & 4,6 \\
\hline Żegotki 2, KCWR & 256 & 5 & 1,9 \\
\hline Żegotki 3, KPCW & 660 & 13 & 1,9 \\
\hline Kuczkowo 5, KPCW & 299 & 9 & 3 \\
\hline Węgierce 12, KPCW & 895 & 34 & 3,7 \\
\hline Brześć Kujawski 4, KCWR & 534 & 19 & 3,5 \\
\hline Smólsk 4, KCWR & 996 & 55 & 5,5 \\
\hline Zagajewice 1, KCWR & 987 & 12 & 1 \\
\hline Wolica Nowa 1, KCWR & 1171 & 168 & 14 \\
\hline Kujawy, faza starsza (KCWR) & 10124 & 418 & 4,1 \\
\hline Kujawy, faza młodsza (KPCW) & 2968 & 108 & 3,6 \\
\hline Kujawy - całość & 13092 & 526 & 4 \\
\hline
\end{tabular}


pozwoliło na zarejestrowanie bardzo niewielkich fragmentów kostnych. Niemniej jednak z Wolicy znane są również liczne szczątki sarny; udział tego zwierzęcia wynosi prawie $40 \%$ wśród gatunków łownych.

Materiały faunistyczne z wczesnoneolitycznych stanowisk z Kujaw charakteryzują się niewielkim odsetkiem kości zwierząt dzikich, rzędu około 3\%. Nie zarejestrowano zależności między wielkością osiedla a udziałem gatunków dzikich. Należało się bowiem spodziewać, iż w obrębie niewielkich, raczej sezonowych osad, odsetek ten powinien być wyższy niż w osadach ze śladami zwartej zabudowy słupowej, które były wykorzystywane przez dłuższy czas, gdzie chów przydomowy mógł być bardziej rozwinięty, co z kolei mogło doprowadzić do niższego zapotrzebowania na mięso zwierząt dzikich i spowodować ich mniejszy udział w materiale osteologicznym. Taka hipoteza, opierająca się na przesłankach ekonomicznych, nie znajduje jednak pokrycia w rzeczywistości - o ile bowiem w Bożejewicach, osiedlu o trwałej zabudowie, prawdopodobnie dość dużym ${ }^{29}$, odsetek ten był rzeczywiście niewielki (zaledwie 2,1\%), to już w Smólsku, gdzie stwierdzono obecność aż trzech budynków mieszkalnych, udział ten sięga 5,5\%. Odsetek tych materiałów był niespodziewanie wysoki również w Wolicy Nowej, gdzie znajdowały się dwa domostwa $\mathrm{z}$ towarzyszącymi im gliniankami, zawierającymi materiał archeozoologiczny.

Najliczniej występującymi gatunkami zwierząt łownych na wczesnoneolitycznych stanowiskach Kujaw są sarna i tur. Ich udział na omawianym terenie wynosi niemal 50\% wszystkich szczątków kostnych takich zwierząt. Zarejestrowano tutaj również sporo szczątków jelenia oraz dzika, a także żółwia błotnego i ryb (głównie za sprawą ich wysokiego odsetka w Wolicy Nowej). Występowanie innych gatunków, takich jak niedźwiedź (Ursus arctos), tchórz (Mustela putorius), wiewiórka (Sciurus vulgaris) czy bóbr (Castor fiber) było epizodyczne (por. ryc. 2).

Wczesnoneolityczne stanowiska kujawskie pod względem zróżnicowania gatunkowego zwierząt dzikich prezentują się niejednorodnie. Na niektórych z nich jest ono zaskakująco duże. Na osadzie w Wolicy Nowej zarejestrowano obecność aż jedenastu taksonów, począwszy od dużych zwierząt łownych, zamieszkujących tereny leśne, takich jak jeleń czy sarna, po liczne gatunki związane ze środowiskiem wodnym. Podobnie duża różnorodność zaobserwowana została w Smólsku, jednak w tym przypadku są to głównie szczątki ssaków. W pozostałych osadach liczba taksonów wynosi średnio pięć czy sześć, lub jedynie dwa, jak ma to miejsce na stanowisku Żegotki 2. Wpływ na taki stan rzeczy może mieć usytuowanie danej osady, mianowicie: jej położenie na granicy kilku różnych ekosystemów, czego efektem może być większe zróżnicowanie gatunków łownych.

\footnotetext{
${ }^{29} \mathrm{~W}$ trakcie badań wykopaliskowych odsłonięte zostały pozostałości jednej chaty słupowej, jednak osada miała prawdopodobnie większy zasięg.
} 


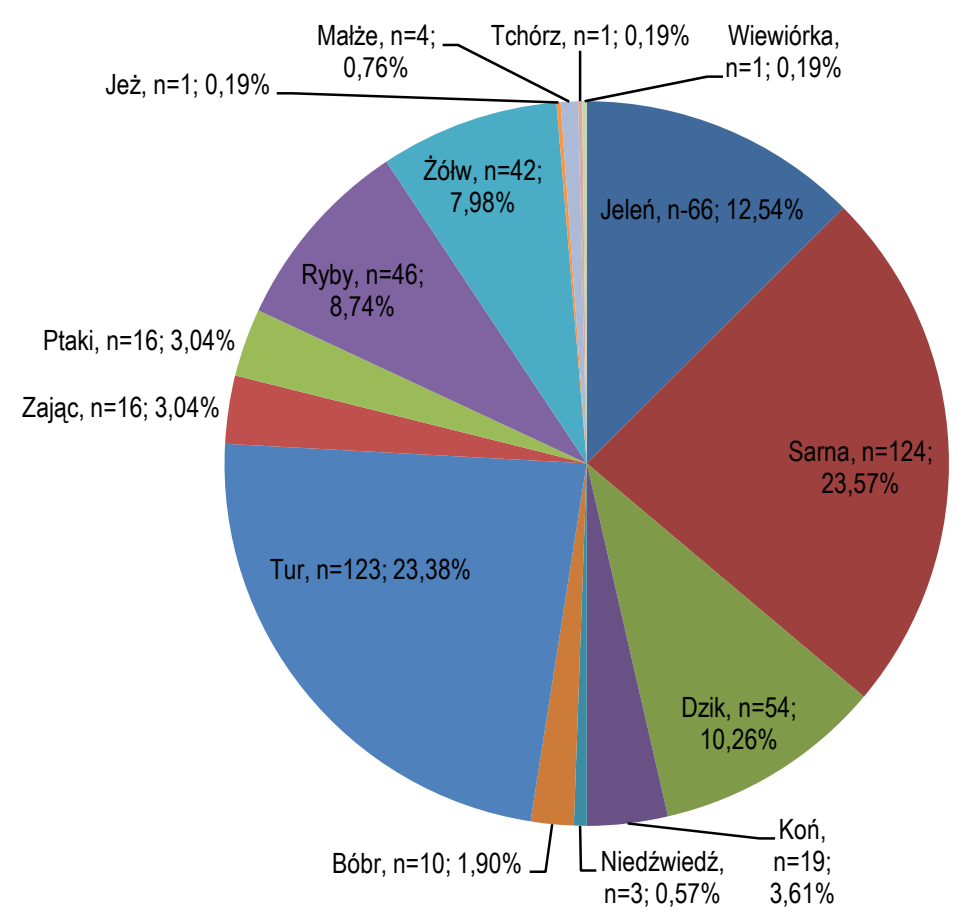

Ryc. 2. Procentowy udział poszczególnych gatunków zwierząt nieudomowionych w regionie Kujaw $(\mathrm{n}=526)$

Fig. 2. Percentage of particular species of non-domestic animals in Kujawy $(n=526)$

Należy również zwrócić uwagę na kontekst, w jakim występują szczątki zwierząt dzikich. W każdym przypadku współwystępowały one z materiałem ruchomym, w obiektach najczęściej określanych jako jamy gliniankowe. Obiekty te pozostawały w ścisłej relacji z budowlami mieszkalnymi, zarówno chatami o konstrukcji słupowej (większość przypadków), jak i ziemiankami (Miechowice). W niektórych przypadkach ślady po budowlach słupowych nie zachowały się, a ich zasięg wyznaczały jedynie towarzyszące im obiekty, najczęściej właśnie glinianki (taka sytuacja miała miejsce w Smólsku).

Osobnego omówienia wymagają przemiany chronologiczne w udziale dzikich zwierząt. W tym celu zastosowano podział na materiały kultury ceramiki wstęgowej rytej (faza starsza) i kultury późnej ceramiki wstęgowej (młodsza faza). Udział gatunków łownych wraz z upływem czasu zmniejszył się nieznacznie - w fazie starszej wyniósł on 4,1\%, natomiast w młodszej - już tylko 3,6\%. W rzeczywistości jednak za wyższy odsetek $\mathrm{w}$ fazie starszej odpowiada rekordowo wysoki udział fauny dzikiej w Wolicy Nowej. Jeżeli pominąć dane z tego stanowiska, to spada on do niespełna 2,7\%, a więc jest niższy niż w fazie młodszej. Z upływem czasu maleje 
także różnorodność gatunków łownych - w fazie starszej mamy do czynienia z dużą liczbą gatunków, wśród których większość występuje w okresie młodszym tylko sporadycznie (por. tab. 1).

\section{Małopolska}

Jak już wspomniano, materiały „wstęgowe” na terenie Małopolski reprezentowane są jedynie przez osadę w Samborcu, gdyż tylko tam zachowały się kości zwierzęce. Całkowita liczba oznaczonych szczątków zwierzęcych jest tu jednak niewielka - wynosi zaledwie 444, z czego 46, czyli niewiele ponad $10 \%$, należy do gatunków dzikich. Różnorodność gatunków łownych jest również dużo mniejsza niż na stanowiskach kujawskich. Najliczniejszym zwierzęciem łownym jest koń, reprezentowany głównie przez kości kończyn. Ponadto zarejestrowano pozostałości jelenia, sarny, a także dzika (jedynie dwa fragmenty kostne), bobra oraz zająca (Lepus europaeus) - po jednym fragmencie kostnym (por. ryc. 3). Znamienny jest stopniowy wzrost udziału zwierząt łownych w poszczególnych fazach kultury ceramiki wstęgowej rytej - o ile $\mathrm{w}$ fazie pierwszej wynosi on zaledwie 4,4\%, o tyle w fazie środkowej wzrasta do 9,3\%, a w ostatniej stanowi aż 14,3\% (por. tab. 1). Pod względem przestrzennej dystrybucji zwierzęcych szczątków kostnych omawiana osada nie różni się zasadniczo od stanowisk z terenu Kujaw - kości zwierząt dzikich przemieszane z materiałem masowym i szczątkami zwierząt domowych zalegały w jamach, których funkcję określono jako glinianki lub też jamy odpadkowe.

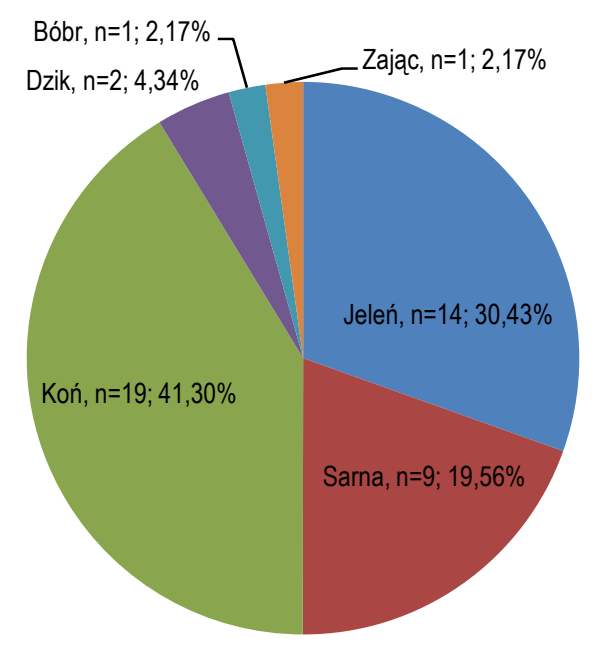

Ryc. 3. Procentowy udział poszczególnych gatunków zwierząt nieudomowionych w regionie Małopolski (stanowisko Samborzec, $\mathrm{n}=46$ )

Fig. 3. Percentage of particular species of non-domestic animals in Małopolska (site Samborzec, $n=46$ ) 


\section{Dorzecze Laby i Soławy}

Na osadzie w Eilsleben zarejestrowano wyjątkowo dużą, zwłaszcza w porównaniu z innymi wczesnorolniczymi stanowiskami Europy Środkowej, liczbę kości zwierzęcych - ponad cztery tysiące. W przeprowadzonej analizie zastosowano podział całego materiału archeozoologicznego na trzy grupy ze względu na ich atrybucję kulturową: (a) starsza kultura ceramiki wstęgowej rytej, (b) młodsza kultura ceramiki wstęgowej rytej oraz (c) kości z obiektów, z których materiał pozwolił jedynie na stwierdzenie, iż przynależą one do omawianej kultury, nie można jednak określić ich przynależności do konkretnej fazy (starszej lub młodszej). Udział kości taksonów dzikich dla całego stanowiska wynosi 11,2\% (w odniesieniu do trzech wspomnianych wyżej grup). Warto zauważyć, iż odsetek tych szczątków z upływem czasu nieznacznie spadał (por. tab. 1).

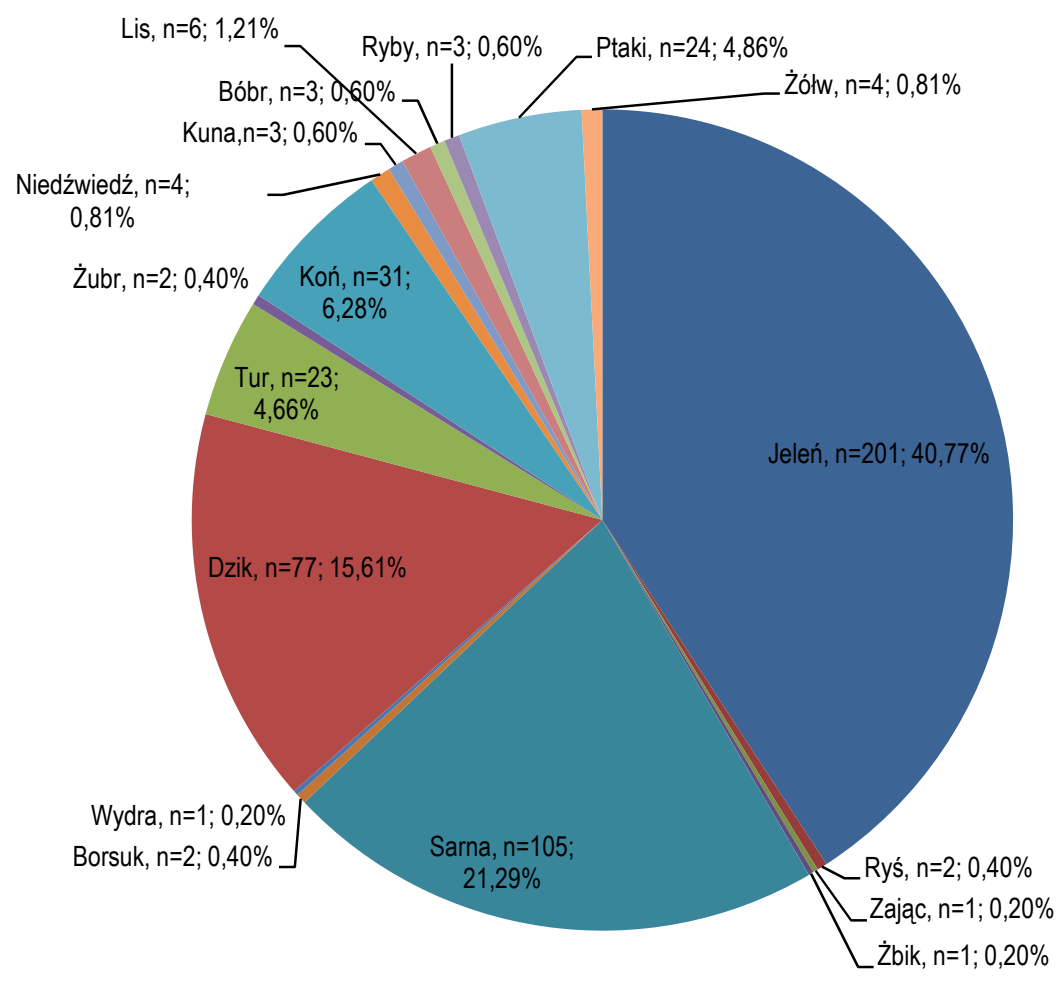

Ryc. 4. Procentowy udział poszczególnych gatunków zwierząt nieudomowionych w regionie dorzecza Łaby/Soławy (stanowisko Eilsleben, $n=493$ )

Fig. 4. Percentage of particular species of non-domestic animals in the Elbe and Saale river basin (site Eilsleben, $\mathrm{n}=493$ ) 
Najliczniej występującym zwierzęciem łownym jest jeleń, a jego udział w tej grupie wynosi ponad $40 \%$. Większość osobników została zabita w wieku dorosłym (powyżej 3 lat) $^{30}$. Drugim pod względem częstości występowania zwierzęciem łownym jest sarna, której udział wynosi ponad 21\%. Dzik stanowi już tylko nieco ponad $15 \%$ wszystkich gatunków łownych. Te trzy gatunki najliczniej występują na omawianym stanowisku, które wyróżnia się nadzwyczajną różnorodnością fauny dzikiej, reprezentowaną aż przez osiemnaście gatunków, m.in. tura czy konia. Sporadycznie występują także takie taksony, jak stanowiący rzadkość w materiałach wczesnoneolitycznych żubr czy gatunki drapieżne, takie jak lis (Vulpes vulpes), niedźwiedź brunatny, kuna leśna (Martes martes), ryś (Lynx lynx) czy żbik (Felis silvestris por. ryc. 4). We wszystkich niemalże obiektach szczątki zwierząt dzikich współwystępują z materiałem masowym, zarówno z ceramiką, jak i narzędziami oraz półsurowcem krzemiennym, a także z kośćmi zwierząt domowych - bydłem, owcą (Ovis aries) i/lub kozą (Capra hirca), świnią. Nie ma tu obiektów zawierających wyłącznie kości zwierząt dzikich w dużych ilościach.

\section{ZNACZENIE NIEUDOMOWIONYCH ZWIERZĄT WE WCZESNYM NEOLICIE}

\section{Gospodarcze znaczenie zwierząt nieudomowionych w Europie Środkowej}

Materiał empiryczny przedstawiony w części analitycznej wskazuje jednoznacznie na obecność łowiectwa w gospodarce pierwszych środkowoeuropejskich rolników. Zajęcie to miało jednak charakter towarzyszący chowowi zwierząt domowych i nigdy nie stanowiło podstawy działań gospodarczych, na co wskazuje procentowy udział fauny dzikiej, w zasadzie nigdy nieprzekraczający $20 \%$ (por. ryc. 5). Ta forma gospodarowania stanowi (obok zbieractwa dzikich roślin) przejaw wykorzystywania zasobów naturalnego środowiska przez mieszkańców osad wstęgowych. Próbując określić rolę dzikich zwierząt, należy wziąć pod uwagę ich różnorodność gatunkową. Podstawową grupę zwierząt dzikich na stanowiskach wczesnoneolitycznych stanowią ssaki, zwłaszcza jeleniowate (jeleń i sarna - por. ryc. 2, 3, 4). Zwierzęta te już $\mathrm{w}$ epoce mezolitu stanowiły najważniejszy cel polowań ${ }^{31}-$ podobnie sytuacja wygląda w czasach dzisiejszych. Głównym powodem ich zabijania we wczesnym neolicie była niewątpliwie chęć zdobycia mięsa, jednak zapewne duże znaczenie miały również skóry tych zwierząt. Prawdopodobnie w niektórych przypadkach przynoszono do osady całą tuszę zabitego zwierzęcia (o czym świadczy obecność wszystkich części anatomicznych szkieletu) celem oskórowania. Mamy tu

\footnotetext{
${ }^{30}$ Döhle 1994.

${ }^{31}$ Wyrost 1994.
} 
również do czynienia ze sporym udziałem poroża tych zwierząt (23\% w przypadku jelenia i $8 \% \mathrm{w}$ przypadku sarny), które służyło do wyrobu narzędzi (toporów i motyk). Ich obecność nie stanowi bezdyskusyjnego dowodu działalności łowieckiej, gdyż poroża mogły być zbierane i przynoszone do osady przez jej mieszkańców. Wydaje się więc zasadne mówienie o trzech sposobach wykorzystania jelenia czy sarny w gospodarce pierwszych rolników: dostarczanie mięsa ${ }^{32}$, poroża oraz skór.

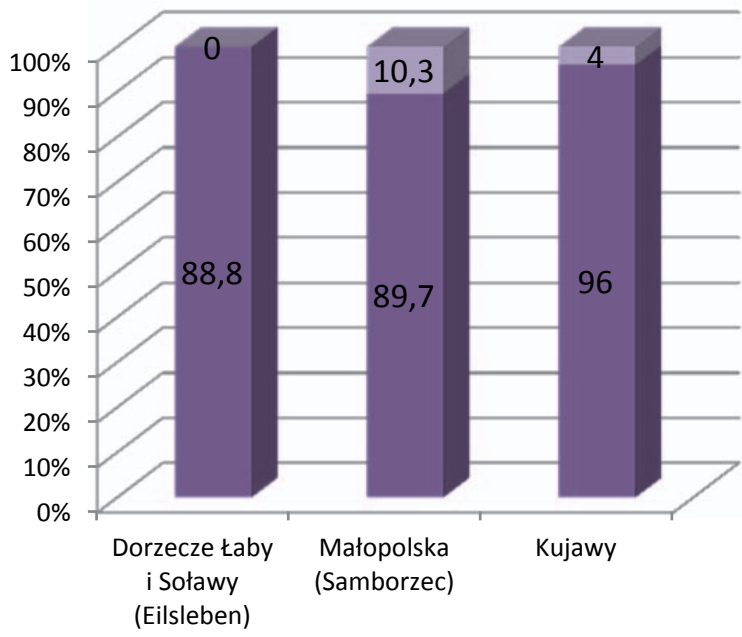

Zwierzęta nieudomowione,

- Zwierzęta udomowione, $n=16866$

Ryc. 5. Procentowe udziały gatunków zwierząt nieudomowionych $w$ trzech analizowanych regionach

Fig. 5. Percentage of particular species of non-domestic animals in the Tyree analysed regions

Drugim co do liczebności zwierzęciem dzikim jest tur, w niektórych przypadkach przewyższa on udział sarny czy jelenia. Można przypuszczać, iż miał on ogromne znaczenie dla pierwszych rolników osiadłych na terenie Europy Środkowej. Niedawne badania genetyczne dowodzą, że w najwcześniejszym okresie neolitu bydło przywędrowało na tereny Europy Środkowej w formie udomowionej ${ }^{33}$, i istnieje prawdopodobieństwo miejscowego krzyżowania się z dzikim turem, zwłaszcza jeżeli weźmie się pod uwagę to, że zwierzęta w tamtym okresie były wypasane zazwyczaj w okolicznych lasach ${ }^{34}$. Należy zauważyć, iż udział tura na analizowanych

\footnotetext{
${ }^{32}$ Świadczy o tym pokonsumpcyjny charakter szczątków kostnych na wszystkich analizowanych stanowiskach (por. np. Döhle 1994; Marciniak 2005; Grygiel 2004).

${ }^{33}$ Bollongino, Burger 2007.

${ }^{34}$ Autorzy sygnalizują taką możliwość, jednak z genetycznego punktu widzenia mogło mieć miejsce jedynie krzyżowanie krowy z dzikim turem, gdyż sytuacja odwrotna została wykluczona przez nich w toku badań DNA (Bollongino, Burger 2007, 184, 185).
} 
stanowiskach jest wysoki jedynie w fazie starszej, a jego znaczenie spada $\mathrm{z}$ upływem czasu. Osobniki obecne w materiale pochodzącym $z$ fazy najstarszej mogły być często potomkami tura i bydła domowego ${ }^{35}$. Nie można też wykluczyć zabijania dorosłych zwierząt w celu schwytania młodych, a następnie ich oswojenia i zwiększenia w ten sposób liczebności stada.

Szczątki dzika są mniej liczne w analizowanym materiale, zwłaszcza jeżeli chodzi o fazę starszą; w fazie młodszej mamy do czynienia z nagłym wzrostem znaczenia tego zwierzęcia. Nie można wykluczać sytuacji podobnej do tej, jaka miała miejsce w przypadku bydła - dziki mogły krzyżować się ze świnią, która została sprowadzona z terenów bałkańskich jako zwierzę domowe. Nie ma przesłanek mówiących o miejscowym, środkowoeuropejskim udomowieniu tego zwierzęcia. Sytuację taką potwierdzają najnowsze badania $\mathrm{DNA}^{36}$. Można tu mówić o procesie dostosowywania stad hodowlanych do miejscowej fauny dzikiej.

Powody polowania na konia nie są jasne. Największy odsetek kości tego zwierzęcia znajduje się w Samborcu. Rozkład części anatomicznych (niski udział dolnych części kończyn, stopy czy głowy, przy jednoczesnym wysokim udziale części tułowia oraz górnych części kończyn) wskazuje na odcinanie kończyn oraz głowy zwierzęcia i przynoszenie do osady jedynie części obfitujących w mięso. Wzorzec ten jednak nie powtarza się w Eilsleben. Można zatem przypuszczać, iż zwierzę to było okazyjnie odławiane w celach konsumpcyjnych, jednak należy zaznaczyć, że zdarzało się to stosunkowo rzadko - częściej i chętniej zapewne polowano na gatunki omówione powyżej. Brakuje przekonywających dowodów na próby udomowienia tego zwierzęcia we wczesnym neolicie na omawianym obszarze.

Omówione powyżej gatunki ssaków miały największe znaczenie w gospodarce wczesnych rolników. Ich kości są najczęściej spotykane w materiałach faunistycznych, zarówno na analizowanych w tej pracy osadach, jak i innych wczesnoneolitycznych stanowiskach w Europie Środkowej. Drugą grupę zwierząt dzikich stanowią ssaki, których obecność na stanowiskach wczesnoneolitycznych jest zdecydowanie rzadsza. Należą do nich zwierzęta drapieżne, takie jak niedźwiedź, lis, ryś, żbik, tchórz, kuna czy też borsuk (Meles meles - por. ryc. 2, 3, 4). Można przypuszczać, iż stanowiły one zagrożenie dla ludzi oraz zwierząt hodowlanych (głównie młodych), co było powodem ich zabijania. $\mathrm{Z}$ tej grupy borsuk żywi się raczej pokarmem roślinnym, a więc mógł on w większym stopniu zagrażać uprawom zbóż. Za szkodnika mógł być uznawany również bóbr, gdyż powodował podtapianie ogródków uprawnych, położonych w pobliżu rzek.

Kolejną grupę zwierząt nieudomowionych stanowią gatunki, których obecność jest wyznacznikiem środowiskowym. Należą do nich szczątki zająca szaraka, spoty-

\footnotetext{
${ }^{35}$ Mogą to być osobniki, co do których nie wiadomo, czy należą do formy domowej czy dzikiej. W opracowaniach spotyka się wyróżnione gatunki umowne, takie jak tur/bydło, lub też, nieco rzadziej, dzik/świnia. W takim przypadku granica między zwierzętami udomowionymi a dzikimi ulega zatarciu.

${ }^{36}$ Larsen, Albarella, Dobney et al. 2007.
} 
kane dość regularnie, choć zawsze w niewielkich ilościach, które mogą świadczyć o znacznym stopniu odlesienia ${ }^{37}$, gdyż gatunek ten bytuje na terenach otwartych łąkach czy polanach. Można przypuszczać, iż na zające, podobnie jak w dzisiejszych czasach, polowano głównie w celach konsumpcyjnych, a być może także w celu pozyskania futra. Żółw błotny natomiast stanowi doskonały wyznacznik środowiska wodnego. Jego szczątki są również dosyć często spotykane na badanych tutaj stanowiskach wczesnoneolitycznych (zwłaszcza na stanowiskach kujawskich, a także w znacznie mniejszym stopniu - Eilsleben). Gatunek ten jest ściśle związany ze środowiskiem wodnym (głównie z wodami stojącymi oraz wolno płynącymi), obfitującym w różnego rodzaju ryby, a także małże (Bivalvia). Żółwie były odławiane i stanowiły ważny element diety. Zarejestrowanie obecności tych zwierząt w materiale kostnym na stanowiskach archeologicznych jest w dużym stopniu zależne od metodyki ich badania. Tradycyjne sposoby eksploracji nie dają takich efektów, jak przesiewanie przez sita czy flotacja wypełnisk obiektów. Pojedyncze szczątki ryb znane są z Łojewa, Węgierec, a także Eilsleben. Na podstawie rozpoznanych gatunków, które udało się zidentyfikować, można wnioskować, iż najwcześniejsi rolnicy często odławiali ryby z rodziny karpiowatych - wzdręgę (Scardinius erythrophthalmus), której szczątki pochodzą z Eilsleben, oraz leszcza (Abramis brama), rozpoznanego w Wolicy Nowej. Celem łowów był również szczupak (Esox lucius), dwukrotnie zarejestrowany w Eilsleben oraz Wolicy Nowej.

Ptaki z badanych stanowisk zostały potraktowane całościowo jako osobna grupa, gdyż nie w każdym przypadku było możliwe dokładne ustalenie, z jakim konkretnym taksonem mamy do czynienia. W materiałach kostnych stwierdzono obecność takich gatunków, jak: żuraw (Grus grus), głuszec (Tetrao urogallus), dzika gęś (Anser anser), cietrzew (Tetrao tetrix), kaczka krzyżówka (Anas platyrhynchos), gołąb (Columba palumbus), puszczyk (Strix aluco) oraz orzeł przedni (Aquila chrysaetos) w Eilsleben. Obecność tego ostatniego jest interesująca, gdyż pozostałe gatunki zamieszkują środowisko wodne (oprócz puszczyka), i stanowią dość łatwy cel do polowań, natomiast orzeł jest drapieżnikiem, zamieszkującym głównie tereny górskie (aczkolwiek w omawianym okresie występował powszechnie na rozległych obszarach Europy Środkowej). Mógł on zostać schwytany przypadkiem lub być obiektem celowego polowania, gdyż gatunek ten prawdopodobnie stanowił zagrożenie dla młodych zwierząt domowych (kóz lub jagniąt).

Przedstawione powyżej rozważania skłaniają do wniosku, iż każdy gatunek lub grupa gatunków nieudomowionych miały nieco inne znaczenie w gospodarce najwcześniejszych rolników osiadłych na terenie Europy Środkowej. Główną ich rolą było dostarczanie mięsa, co było istotne zwłaszcza w okresach głodu. Gospodarka ludów wstęgowych charakteryzowała się niską produktywnością oraz niską odpor-

\footnotetext{
${ }^{37}$ Por. np. Samsonowicz 1991 (cyt. za: Grygiel 2004, 576); Döhle 1994.
} 
nością na wszelakie niekorzystne czynniki zewnętrzne ${ }^{38}$, a zwłaszcza złe warunki pogodowe. Zimne, deszczowe lata powodowały niższe zbiory, a często także spadek liczebności hodowlanych stad. Taki sam skutek mogły przynosić szczególnie mroźne zimy - z powodu braku paszy powstawała konieczność regulacji liczby zwierząt w stadzie. Część słabszych osobników mogła także sama paść podczas przedłużających się niskich temperatur. Wraz z nadejściem wiosny uzupełniano niedobory pożywienia. Najefektywniejszą strategią postępowania było wówczas skorzystanie z naturalnych zasobów środowiska. Być może chwytano wówczas młode tury w celu ich oswojenia i zwiększenia liczebności stada. Uzasadnieniem takiej tezy mogą być badania, jakie przeprowadzono $w$ rejonie Zurychu ${ }^{39}$, gdzie analizowano różnice w zawartości węgla $\mathrm{C}^{13} \mathrm{w}$ atmosferze ${ }^{40}$. Jego wysoka zawartość wskazywała na fazy zimna, a niska - na okresy cieplejsze i suche ${ }^{41}$. Dane te pokrywają się z występowaniem kości zwierząt dzikich na omawianych stanowiskach. W okresach chłodniejszych, charakteryzujących się słabymi plonami, ich udział wzrasta i dochodzi nawet do $80 \%$ wszystkich szczątków kostnych. Wyniki te uzyskano dla okresu nieco późniejszego niż wczesny neolit (badania dotyczyły lat 4300-2700 BC), jednak jest to ważny czynnik uprawomocniający tezę o wpływie niekorzystnych fluktuacji klimatycznych na charakter gospodarki, co w tym przypadku przejawia się zwiększoną rolą łowiectwa w okresach niedogodnych warunków pogodowych.

Warto zwrócić uwagę, że w kolejnych okresach doszło na badanych obszarach do niewielkiego wzrostu znaczenia fauny dzikiej. Może to sugerować powolną adaptację rolników wstęgowych do nowego środowiska lub też może być przejawem udoskonalenia technik łowieckich. Wraz z upływem czasu od początków kolonizacji wczesnorolniczej na Kujawach osadnictwo wstęgowe stopniowo zajmowało coraz to nowe tereny, znajdujące się poza obszarem występowania czarnoziemów. Przełożyło się to na spadek produktywności rolniczej, co w konsekwencji powodowało konieczność częstszego sięgania do zasobów środowiska naturalnego ${ }^{42}$.

Pojawia się pytanie: dlaczego polowania odgrywały niewielką rolę w omawianym okresie? Odpowiedzi na nie należy szukać, odwołując się do argumentów ekonomicznych. Można sądzić, iż chów zwierząt obarczony jest mniejszym ryzykiem niepowodzenia. Jednak, jak już wspomniano, zwierzęta hodowlane są również w mniejszym stopniu odporne na wszelkie niekorzystne czynniki zewnętrzne, takie jak choroby czy złe warunki pogodowe, zwłaszcza w przypadku posiadania niewielkich stad. Drugą kwestią jest allochtoniczny charakter kultur wstęgowych, które

\footnotetext{
${ }^{38}$ W literaturze gospodarkę ową określa się więc mianem „ekstensywnej” (por. np. Bogaard 2004; 2005).

${ }^{39}$ Schibler, Jacomet 2010.

${ }^{40}$ Stuiver, Reimer, Bard et al. 1998 (cyt. za: Schibler, Jacomet 2010, 178).

${ }^{41}$ Np. Magny 1992 (cyt. za: Schibler, Jacomet 2010, 178).

${ }^{42}$ Marciniak 2013, 5.
} 
przybyły na obszar Europy Środkowej w ukształtowanej formie i z własnym modelem gospodarczym. Tereny owe pod względem warunków naturalnych różniły się od rodzimych terenów naddunajskich, z których społeczności wstęgowe przybyły. Poświęcając większość czasu na uprawę pól oraz chów zwierząt, mieszkańcy osad nie koncentrowali się zapewne na polowaniach, a co za tym idzie, nie posiadali dużych umiejętności łowieckich ${ }^{43}$. Sytuacja ta mogła zmienić się z czasem, w procesie dostosowywania się do otaczającego środowiska. Możliwe, iż decydującą rolę miały tu wielokrotnie wspominane niekorzystne czynniki klimatyczne, które powodowały konieczność sięgania po inne rozwiązania niż rolnictwo czy chów zwierząt. Można przypuszczać, iż gospodarka oparta na wytwarzaniu żywności, uzupełniana od czasu do czasu polowaniami, które dostarczały zarówno dodatkowego pożywienia, a także skór oraz poroża do wyrobu narzędzi, była najlepszym rozwiązaniem we wczesnym neolicie Europy Środkowej.

Struktura gatunkowa zwierząt dzikich na poszczególnych stanowiskach może być uznana $\mathrm{z}$ jednej strony za odzwierciedlenie środowiska naturalnego, a $\mathrm{z}$ drugiej za odbicie relacji człowieka $\mathrm{z}$ tym środowiskiem. Mając do czynienia z taką różnorodnością gatunków łownych na analizowanym obszarze, można stwierdzić, iż społeczności wstęgowe osiedlały się na pograniczu różnych ekosystemów. Świadczy o tym obecność gatunków zamieszkujących tereny leśne, a także całej grupy taksonów związanych ze środowiskiem wodnym (ptaki, ryby, żółw). Niewielka ilość szczątków zwierząt zasiedlających środowisko otwarte (zając szarak) wskazuje na niewielkie areały, jakie zajmowały łąki, a także na przewagę pokrywy leśnej. Obecność gatunków, które dziś zostały zepchnięte do niewielkich enklaw (np. niedźwiedź brunatny, orzeł przedni, ryś), bądź całkowicie wyginęły (tur), wskazuje także na ich powszechne występowanie w tamtych czasach. Niewielki zakres polowań we wczesnym neolicie nie spowodował zapewne poważnego naruszenia struktury środowiska naturalnego.

\section{Społeczne znaczenie zwierząt nieudomowionych w Europie Środkowej}

Próbując wyjaśnić, jakie czynniki natury społecznej wpływają na niewielkie zainteresowanie zwierzętami nieudomowionymi we wczesnym neolicie, nie można zapominać o charakterze i pochodzeniu kultur wstęgowych. Ich kolonizatorski charakter skłania do sformułowania tezy, iż społeczności te pragnęły zaakcentować swoją odmienność od miejscowej, zbieracko-łowieckiej ludności, co jednocześnie

\footnotetext{
${ }^{43}$ Nie są znane dokładne sposoby polowań. J. Kruk i S. Milisauskas $(1999,52)$ stwierdzają, iż używano do tego celu łuku (znaleziska grotów strzał z północno-zachodniej części występowania kultury ceramiki wstęgowej rytej) lub też sideł i paści (na wschodnich terenach występowania owej kultury brakuje znalezisk grotów strzał).
} 
mogło skutkować zacieśnieniem więzi i zwiększeniem poczucia przynależności do własnej grupy. Jednym z jego przejawów mogło być niskie zainteresowanie czynnościami, które są charakterystyczne dla ludności mezolitycznej (łowiectwem). W kulturze późnej ceramiki wstęgowej mamy do czynienia z trzema ważnymi zjawiskami. Po pierwsze, następuje dezintegracja tej wyjątkowo jednolitej jednostki na wiele kultur lokalnych ${ }^{44}$. Dochodzi też do przekształceń w osadnictwie, skutkujących poszerzeniem ekumeny wstęgowej na wcześniej niezajmowane tereny ${ }^{45}$. Ma też miejsce wzrost eksploatacji dzikiej fauny, na co wskazuje nieznaczne zwiększenie jej odsetka na badanych stanowiskach. Wymienione trzy elementy sugerują, iż ludność wstęgowa wraz z upływem czasu od zasiedlenia nowych terenów przestawała się izolować od ludności mezolitycznej, co przejawiało się we wkraczaniu na nowe tereny, zajmowane dotąd przez łowców-zbieraczy. Zanikała także konieczność podkreślania więzi grupowych oraz innego trybu życia. Przemiany te nadal miały ograniczony zasięg i zapewne nie spowodowały one zasadniczej zmiany podstaw ekonomicznych ludności kultury ceramiki wstęgowej. Owe trzy elementy stanowiły jedynie przejaw dostosowania się pierwszych rolników do lokalnych warunków i otaczającego środowiska.

$\mathrm{Z}$ omawianym zagadnieniem wiążą się dwie zasadnicze kwestie. Po pierwsze, nie wiadomo, czy pierwsi rolnicy rzeczywiście nie chcieli korzystać z naturalnych zasobów środowiska, czy po prostu nie mogli tego robić, gdyż jako przybysze $\mathrm{z}$ w pełni ukształtowanym systemem gospodarczym mieli niewielkie pojęcie o sposobach polowań, a także, co się z tym wiąże, nie rozumieli trybu życia poszczególnych gatunków dzikich zwierząt w środkowoeuropejskiej strefie umiarkowanej. Byli wyspecjalizowani $\mathrm{w}$ chowie zwierząt, a przede wszystkim $\mathrm{w}$ uprawie roślin. D.K. Jordan ${ }^{46}$ dokonuje nawet podziału cech osobowości, jakie posiadali rolnicy i łowcy-zbieracze. Ci pierwsi mieli się odznaczać m.in. cierpliwością, kooperatywnością czy też niechęcią do podejmowania ryzyka. Nie wiadomo, w jakim stopniu owe cechy miałyby być powszechne w danej społeczności rolniczej. Można natomiast przypuszczać, iż musiało minąć co najmniej kilkadziesiąt lub nawet kilkaset lat, aby mogli oni dostosować się do otaczającego środowiska, co w rezultacie doprowadziło do zwiększania skuteczności polowań. Okazało się to niewątpliwie przydatne ze względu na wspomniane czynniki ekonomiczne (uzupełnianie niedostatków pożywienia w okresie nieurodzaju).

Drugą kwestią jest możliwość ustalenia, w jakim stopniu opisana powyżej sytuacja może znajdować uzasadnienie w ewentualnych kontaktach z ludnością mezoli-

\footnotetext{
${ }^{44}$ Bezpośrednio nas interesująca kultura późnej ceramiki wstęgowej, a także takie jednostki, jak krąg lendzielsko-polgarski, kultura malicka czy kultura rösseńska (np. Czerniak 1994).

${ }^{45}$ Żyzne gleby lessowe czy czarne ziemie - zjawisko to miało jednak niewielki zasięg, a społeczności wstęgowe nadal chętnie trzymały się tych samych terenów co ich poprzednicy (Kruk, Milisauskas 1999, 61, 62).

${ }^{46}$ Jordan 2009.
} 
tyczną. W kulturze ceramiki wstęgowej rytej surowiec krzemienny najprawdopodobniej pochodził z wymiany, gdyż większość surowca na kujawskich osadach tej kultury ma swoje źródła na terenach Małopolski. Sugeruje to, że pierwsi rolnicy byli w niewielkim stopniu zainteresowani eksploatacją miejscowych złóż i woleli importować krzemień, zwłaszcza czekoladowy ${ }^{47}$, z terenów położonych poza bezpośrednim osadnictwem wczesnorolniczym, zamieszkiwanych przez społeczności łowiecko-zbierackie kultury janisławickiej ${ }^{48}$. Podobny model pojawia się na terenie Dolnej Nadrenii, gdzie widoczne są oddziaływania miejscowych grup o tradycji mezolitycznej $^{49}$. Zainteresowanie lokalnym surowcem na Kujawach pojawia się dopiero w kulturze późnej ceramiki wstęgowej ${ }^{50}$. Można ten fakt skorelować ze wzrostem udziału fauny dzikiej i potraktować jako jeden z przejawów dostosowania się społeczności wstęgowych do lokalnego środowiska. Przejawia się to w aktywnym korzystaniu z zasobów naturalnych: w intensyfikacji polowań, na co wskazuje mniejsza różnorodność gatunków łownych w okresie późniejszym, sugerująca celowość polowań na pewne określone zwierzęta, głównie jelenia i sarnę, oraz w eksploatacji i obróbce miejscowych złóż krzemiennych. Drugi z przejawów wspomnianej wymiany mogą stanowić znaleziska siekier gładzonych poza terenami objętymi bezpośrednim osadnictwem wstęgowym ${ }^{51}$. Na tej podstawie można przypuszczać, iż kontakty z ludnością mezolityczną miały charakter głównie pokojowy ${ }^{52}$. Niemniej jednak nie ma bezpośrednich dowodów na akulturację w najwcześniejszych fazach kultury ceramiki wstęgowej rytej na terenie Kujaw ${ }^{53}$. Przypuszcza się raczej, iż w tej

\footnotetext{
${ }^{47}$ Kabaciński 2010. Autor ten ocenia, iż średni udział tego surowca w inwentarzach wstęgowych wynosił przeciętnie 51\% (Kabaciński 2010, 90).

${ }^{48}$ Kozłowski, Kozłowski 1977 (cyt. za: Domańska 1988, 84). W tym samym artykule autorka wskazuje jednak na odmienne sposoby obróbki surowca krzemiennego, co może sugerować, iż społeczności wstęgowe samodzielnie zaopatrywały się w niego. Na taką możliwość wskazują także wyniki najnowszych badań (por. np. Kabaciński 2010, 182, 183)

${ }^{49}$ Newell (cyt. za: Lech 1979, 132).

${ }^{50}$ Domańska 1988, 89; Kabaciński 2010, 184.

${ }^{51}$ Vanmontfort 2008 - dane odnoszą się do zachodniej strefy występowania osadnictwa wczesnorolniczego.

${ }^{52}$ Nie można jednak zapominać o licznych dowodach konfliktów zbrojnych, pochodzących zwłaszcza z terenów Europy Zachodniej - przykładem może być tanatocenoza z Asparn-Schletz (Golitko, Keeley 2007) czy Herxheim (Orschiedt, Haidle 2006). Uważa się również, że dowodem na istnienie wrogich kontaktów między ludnością łowiecko-zbieracką a wczesnoneolityczną są ślady po ogrodzeniach, jakimi otoczone były niektóre osady, upowszechniające się w kulturze późnej ceramiki wstęgowej (są one jednak obecne także w najwcześniejszej fazie neolitu - przykładem mogą być pozostałości umocnień ze starszej kultury ceramiki wstęgowej z Eilsleben). Osady takie kojarzone są przede wszystkim z Europą Zachodnią, chociaż tego typu przypadki znane są także na terenie ziem polskich (osada w Osłonkach, por. Grygiel 2008, 476, czy w Biskupinie). Często jednak badacze przypuszczają, iż miały one charakter rytualny i łączenie ich z obronnością wydaje się w większości przypadków bezzasadne (por. Vanmontfort 2008).

${ }^{53}$ Marciniak 2008, 117.
} 
strefie kontakty miały charakter epizodyczny i nie była prowadzona regularna wymiana, a jeżeli nawet można uznać ją za możliwą, to dotyczyła ona najprawdopodobniej jedynie surowców krzemiennych, a ludność wstęgowa zajmowała się łowiectwem przede wszystkim we własnym zakresie, zwłaszcza że enklawy osadnictwa wczesnoneolitycznego położone były w znacznym oddaleniu od terenów zajmowanych przez ludność o tradycji mezolitycznej. Ważnym czynnikiem ograniczającym kontakty mogło być także silne poczucie przynależności do własnej gru$\mathrm{py}^{54}$, obecne wśród najwcześniejszych rolników. Z czasem więzi te uległy rozluźnieniu, co wynikało z wyjścia osadnictwa poza strefę czarnoziemów i intensyfikacji kontaktów z miejscową ludnością mezolityczną ${ }^{55}$.

Wiele trudności wiąże się z określeniem, w jaki sposób zwierzęta nieudomowione były postrzegane przez ludy wstęgowe. Nie wiadomo, czy miały taki sam status jak gatunki domowe, czy też stanowiły pewien rodzaj tabu żywieniowego ${ }^{56}$. Przynależąc do sfery dzikiej, stanowiły uosobienie czegoś nieznanego i obcego. Dyskusyjną kwestią jest jednak to, czy wczesnoneolityczni rolnicy rozumieli udomowienie w dzisiejszym znaczeniu tego słowa i czy myśleli takimi opozycyjnymi kategoriami (domowe/dzikie ${ }^{57}$ ). Obecnie jest to podawane w wątpliwość ${ }^{58}$. Można przypuszczać, iż wczesnoneolityczny człowiek na pewno bał się zwierząt drapieżnych i niebezpiecznych, i starał się mieć z nimi jak najmniej do czynienia. Zupełne inaczej postrzegane były zwierzęta dające się upolować i dostarczające produktów potrzebnych do przeżycia, takich jak mięso, skóry czy poroże. Sytuacja staje się bardziej skomplikowana w przypadku dzika oraz tura. O ile krzyżowanie się tego pierwszego z domową świnią jest bardziej prawdopodobne niż w przypadku tura i bydła domowego, o tyle najprawdopodobniej dzik nie był postrzegany jako dzika „wersja” świni domowej, lecz jako zupełnie inny gatunek ${ }^{59}$.

Przyjmując tezę o zakazach żywieniowych dotyczących zwierząt nieudomowionych, należy pamiętać, iż chociaż na każdym analizowanym stanowisku znajdują się szczątki tych zwierząt, to jednak zazwyczaj są to niewielkie ilości, co może stanowić potwierdzenie takich przypuszczeń. Jeżeli dodać do tego przywoływane wyżej ryzyko związane z polowaniem, wydaje się, iż pierwsi rolnicy nie polegali w znaczącym stopniu na powodzeniu lub jego braku podczas polowania i woleli ograni-

\footnotetext{
${ }^{54}$ Marciniak 2008, 125, 126.

${ }_{55}^{55}$ Marciniak 2013, 5.

${ }^{56}$ Marciniak 2005, 205.

${ }^{57}$ Stwierdzenie to stanowi polemikę z klasycznym już dziś dziełem Iana Hoddera, w którym autor podkreśla istnienie opozycji domus/agrios (domowe/dzikie) jako nierozerwalnie związanych ze światem neolitu (Hodder 1990).

${ }^{58}$ Pollard 2006, 136; Ray, Thomas 2003 (cyt. za: Cummings, Harris 2011, 13); Russell 2002.

${ }^{59}$ Wnioski te odnoszą się wprawdzie do terenów Wielkiej Brytanii, jednak chodzi tu o odkrycie pewnej prawidłowości, jaka rządziła relacjami ludzie-zwierzęta w całym neolicie (por. Cummings, Harris 2011, 12, 14).
} 
czać tę czynność do minimum. Wynikać to mogło także z licznych obwarowań i zakazów żywieniowych, które nie pozwalały na zbyt częste spożywanie mięsa dzikich zwierząt. Nie jest wykluczone, iż owe tabu łamano w okresie większego głodu lub w czasie ważnych uroczystości czy ceremonii. Mięso dzikich zwierząt nie byłoby wtedy traktowane jako zwykły pokarm jedzony na co dzień. Należy jednak zaznaczyć, że chociaż taka sytuacja jest całkiem prawdopodobna, to brakuje wyraźnego oddzielania miejsc deponowania kości zwierząt domowych od dzikich. Na żadnym $\mathrm{z}$ analizowanych $\mathrm{w}$ tej pracy stanowisk nie zarejestrowano obiektu, który zawierałby wyłącznie szczątki zwierząt dzikich. Były one zawsze wymieszane ze szczątkami fauny domowej i sprawiały wrażenie, iż zostały przypadkowo wrzucone razem z nimi do jamy odpadkowej, zazwyczaj wraz z innymi odpadkami, takimi jak potłuczone naczynia czy odłupki krzemienne. Jeżeli więc zwierzęta dzikie traktowane były w jakiś szczególny sposób (czyli jedzono ich mięso w czasie ceremonii czy święta), to szczątki pokonsumpcyjne pochodzące od nich traktowano jak zwykłe odpadki. Nie zaobserwowano również żadnych prawidłowości w przestrzennej dystrybucji kości zwierząt dzikich na analizowanych stanowiskach, poza jednym wyjątkiem. W Eilsleben odsetek fauny dzikiej jest wyższy w rowie otaczającym osadę niż w obiektach mieszkalnych, co może sugerować, iż gatunki nieudomowione były częściej konsumowane poza obrębem osady.

Ostatnią kwestią przy wyjaśnianiu społecznego znaczenia zwierząt dzikich jest zagadnienie domniemanych nierówności społecznych, a co za tym idzie - także ekonomicznych, które miały występować już w okresie wczesnego neolitu ${ }^{60}$. Wydają się one stosunkowo niewielkie, jeżeli porówna się je na przykład z okresem wczesnej epoki brązu. Niemniej jednak pewne domostwa w kulturach wstęgowych mogły dysponować liczebniejszymi stadami zwierząt hodowlanych oraz większym areałem upraw (mogło to wynikać nie tyle z wyższego statusu, ile z większej liczby osób w danym gospodarstwie, które pomagały przy pracy w polu), co czyniło je mniej odpornymi na skutki niekorzystnych warunków pogodowych oraz wymierania zwierząt. Rodziny (czy też domostwa), które posiadały mniejszą liczbę zwierząt domowych, zmuszone były częściej korzystać z zasobów środowiska naturalnego i podejmować próby polowań, gdyż dzika fauna nie stanowiła niczyjej własności ${ }^{61}$, a jej obecność stwarzała okazję do uzupełnienia niedostatków w pożywieniu. Rola zwierząt nieudomowionych byłaby więc $\mathrm{w}$ takim przypadku wyznacznikiem statusu materialnego. Niestety teza ta nie daje się zweryfikować w badanym materiale empirycznym z dwóch zasadniczych powodów. Po pierwsze, w osadach kultur wstęgowych brakuje wyraźnego rozróżnienia zabudowy; wszystkie domy są do siebie podobne i niemożliwe jest stwierdzenie, który z nich wyróżnia się większym bogac-

\footnotetext{
${ }^{60}$ Jordan 2009; Schmitt, Lupo 2008; Bogucki 1996.

${ }^{61}$ Russell 2002.
} 
twem od innych ${ }^{62}$. Drugim powodem nieweryfikowalności tej tezy jest fakt, iż analizowane stanowiska są w większości niewielkie i składają się najczęściej z jednego domostwa.

Powyżej przedstawiono kilka hipotez, które miały pozwolić na określenie, jakie znaczenie mogło być przypisywane zwierzętom nieudomowionym we wczesnym neolicie. Mogły do nich należeć: chęć aakcentowania odmienności, nieznajomość nowego środowiska, tabu żywieniowe, ewentualne wpływy ludności mezolitycznej czy wyznacznik statusu materialnego. Skłonienie się do którejś z tych hipotez zależy w dużej mierze od charakteru dostępnych źródeł i możliwości weryfikacji. W analizowanym materiale można znaleźć przesłanki, które pozwalają częściowo uprawomocnić każdą z tych hipotez. Nie wykluczają się one wzajemnie i z pewnością można stwierdzić, że fakt niskiego udziału zwierząt dzikich we wczesnym neolicie spowodowany był przez wiele czynników. Należy także zaznaczyć, iż o ile znaczenie zwierząt dzikich w perspektywie gospodarczej daje się dość dobrze udokumentować w badanym materiale empirycznym, o tyle jednoznaczne określenie, jaką rolę społeczną odgrywały zwierzęta nieudomowione, pozostaje w sferze przypuszczeń, które na dodatek nie zawsze są weryfikowalne (przykładem może być brak wyraźnego rozgraniczenia gatunków dzikich od domowych w deponowanych szczątkach kostnych na stanowiskach). To sprawia, iż czynniki natury społecznej nie są czytelne w takim samym stopniu jak zmienne ekonomiczne.

\section{UWAGI KOŃCOWE}

Przedstawiona analiza materiałów empirycznych i ich interpretacja wskazują, iż określenie roli, jaką odgrywały zwierzęta nieudomowione w środkowoeuropejskim wczesnym neolicie, jest zagadnieniem wieloaspektowym i złożonym. Pozwala stwierdzić, iż nie można traktować fauny dzikiej jako jednolitej kategorii, badanej w relacji do zwierząt domowych, gdyż mamy tu do czynienia z dużą różnorodnością gatunków łownych, zamieszkujących różne typy środowiska naturalnego. Należy także zaznaczyć, iż zastosowany w niniejszym artykule podział na dwie perspektywy, każący oddzielać sferę gospodarczą od społecznej, jest umowny. W omawianym okresie najprawdopodobniej nie funkcjonowały one jako oddzielne kategorie, lecz przenikały się wzajemnie ${ }^{63}$. Dlatego też trzeba podkreślić, iż obydwie perspektywy (gospodarcza i społeczna) i wynikające stąd odmienne procedury analityczne źródeł

\footnotetext{
${ }^{62}$ Uwaga to odnosi się jednak tylko do badanego obszaru; takie prawidłowości zostały natomiast dostrzeżone w strefie zachodniej - na francuskim stanowisku Cuiry-lès-Chaudardes obiekty towarzyszące mniejszym domostwom charakteryzują się nieco większym odsetkiem zwierzyny łownej w materiale kostnym niż takie same obiekty występujące w sąsiedztwie większych domów (Bakels 2009, 52).

${ }^{63}$ Por. np. Buchowski 1997.
} 
przynoszą wnioski dotyczące znaczenia dzikich zwierząt, które wzajemnie się nie wykluczają.

Pozostaje niemożliwe do ustalenia, w jakim stopniu serie kostne pozyskane ze stanowisk archeologicznych odzwierciedlają rzeczywistą strukturę konsumpcji poszczególnych gatunków. Jeżeli przyjąć, iż tusze zwierząt dzikich były w każdym przypadku przynoszone do osady i konsumowane na miejscu, to twierdzenie o niewielkim udziale mięsa gatunków dzikich wydaje się uzasadnione. Nie można natomiast stwierdzić, czy gatunki nieudomowione były także konsumowane poza osadą. Jeżeli to się zdarzało, i szczątki tych zwierząt były deponowane w miejscu ich upolowania, to hipoteza ta pozostanie nieweryfikowalna ze względu na brak dowodów w postaci szczątków kostnych występujących na terenie osad.

\section{BIBLIOGRAFIA}

Bakels C.C.

2009 The Western European Loess Belt-Agrarian History 5300 BC-1000 AD, Leiden.

Bogaard A.

2004 Neolithic farming in central Europe: an archaeobotanical study of crop husbandry practices, Routledge, Abingdon, Oxon, New York.

2005 "Garden Agriculture" and the Nature of Early Farming in Europe and the near East, World Archaeology 37/ 2, s. 177-196.

Bogucki P.

1996 Sustainable and unsustainable adaptations by early farming communities of Northern Poland, Journal of Anthropological Archaeology 15, s. 289-311.

Bogucki P., Grygiel R.

1981 Early Neolithic Sites at Brześć Kujawski, Poland: Preliminary Report on the 1976-1979 Excavations, Journal of Field Archaeology 8/1, s. 9-27.

1986 Early Neolithic Sites at Brześć Kujawski, Poland: Preliminary Report on the 1980-1984 Excavations, Journal of Field Archaeology 13/2, s. 121-137.

1993 The first farmers of Central Europe. A survey article, Journal of Field Archaeology 20/4, s. $399-426$

Bollongino R., Burger J.

2007 Neolithic cattle domestication as seen from ancient DNA, Proceedings of the British Academy 144, s. 165-87.

Buchowski M.

1997 Wspólnota interpretacyjna: czy archeologia jest potrzebna antropologii?, Poznań.

Cummings V, Harris O.

2011 Animals, people and places: the continuity of hunting and gathering practices across the Mesolithic-Neolithic transition in Britain, European Journal of Archaeology 14/3, s. 361-382.

Czerniak L.

1992 Węgierce, gm. Pakość, stanowisko 12, woj. Bydgoskie. Osada z fazy Ia kultury późnej ceramiki wstęgowej, Sprawozdania Archeologiczne 44, s. 31-47. 
1994 Wczesny i środkowy okres neolitu na Kujawach: 5400-3650 p.n.e., Poznań.

1998 Najstarsi rolnicy [w:] Gazociag pełen skarbów archeologicznych/Pipeline of archaeological treasures, red. M. Chłodnicki, L. Krzyżaniak, Poznań, s. 23-36.

Döhle H.-J.

1994 Die linienbandkeramischen Tierknochen von Eilsleben, Börderkreis: Ein Beitrag zur neolitischen Haustierhaltung und Jagd in Mitteleuropa, Halle.

Domańska L.

1988 Recepcja małopolskich surowców krzemiennych wśród kujawskich społeczeństw cyklu wstęgowego [w:] Kontakty pradziejowych społeczeństw Kujaw z innymi ludami Europy, red. A. Cofta- Broniewska, Inowrocław, s. 81-92.

Golitko M., Keeley L.H.

2007 Beating ploughshares back into swords: warfare in the Linearbandkeramik, Antiquity 81, s. 332-342.

Grygiel R.

2004 Neolit i początki epoki brąu w rejonie Brześcia Kujawskiego i Ostonek, t. 1: Wczesny neolit. Kultura ceramiki wstęgowej rytej, Łódź.

2008 Neolit i początki epoki brąu w rejonie Brześcia Kujawskiego $i$ Osłonek, t. 2, cz. 2: Środkowy neolit, grupa brzesko-kujawska kultury lendzielskiej, Łódź.

Hayden B.

2003 Were luxury foods the first domesticates? Ethnoarchaeological perspectives from Southeast Asia, World Archaeology 34/ 3, s. 458-469.

Hodder I.

1990 The Domestication of Europe: Structure and Contingency in Neolithic Societies, Oxford.

1995 Czytanie przeszłości, Poznań.

Honkisz B.

2011 Gospodarcze i spotecznie znaczenie nieudomowionych zwierzat dla spoteczności wczesnoneolitycznych $w$ Europie Środkowej, [maszynopis pracy magisterskiej, Biblioteka Instytutu Prahistorii UAM] Poznań.

Jordan D.K.

2009 Living the Revolution. The Neolithic (Essay 3).

http://dss.ucsd.edu/ dkjordan/arch/neolithic/Neo3-LivRev.html

Kabaciński J.

2010 Przemiany wytwórczości krzemieniarskiej społeczności kultur wstęgowych strefy wielkodolinnej Niżu Polskiego, Poznań.

Kauffmann D.

1977 Entdeckung und Vermessung einer befestigten linienbandkeramischen Siedlung bei Eilsleben, Kr.Wanzleben, Zeitschrift für Archäologie 11, s. 93-100.

Kruk J., Milisauskas S.

1999 Rozkwit i upadek społeczeństw rolniczych neolitu/The rise and fall of neolithic societies, Kraków.

Kruk J.

1980 Gospodarka w Polsce południowo-wschodniej w V-III tysiącleciu p.n.e., WrocławWarszawa-Kraków-Gdańsk.

Kulczycka-Leciejewiczowa A.

2008 Samborzec. Studium przemian kultury ceramiki wstegowej rytej, Wrocław. 
Larsen G., Albarella U., Dobney K., Rowley-Conwy P., Schibler J., Tresset A., Vigne J.-D., Edwards C.J., Schlumbaum A., Dinu A., Bălăçsescu A., Gaynor D., Tagliacozzo A., Manaseryan N., Miracle P., Van Wijngaarden-Bakker L., Masseti M., Bradley D.G., Cooper A.

2007 Ancient DNA, pig domestication, and the spread of the Neolithic into Europe, Proceedings of the National Academy of Sciences 104/39, s. 15276-15281.

Lech J.

1979 Krzemieniarstwo w kulturze społeczności ceramiki wstęgowej rytej w Polsce. Próba zarysu [w:] Poczatki neolityzacji Polski południowo-zachodniej, red. W. Wojciechowski, Wrocław, s. 121-136.

Makowiecki D.

1989 Materiał kostny zwierzęcy z osady ludności kultury późnej ceramiki wstęgowej w Węgiercach woj. bydgoskie, Roczniki Akademii Rolniczej w Poznaniu 198/13, s. 13-29.

Mallory J.P., Douglas Q. Adams

1997 Encyclopedia of Indo-European Culture, London.

Marciniak A.

1996 Archeologia $i$ jej źródła. Materiaty faunistyczne w praktyce badawczej archeologii, Warszawa-Poznań.

2005 Placing Animals in the Neolithic: Social zooarchaeology of prehistoric farming communities, London.

2008 Interactions Between Hunter-Gatherers and Farmers in the Early and Middle Neolithic in the Polish Part of the North European Plain [w:] Time and change, red. R. Layton, H. Maschner, D. Papagianni, Oxford.

2013 Origin of Stock - Keeping and Spread of Animal Exploitation Strategies in the Early and Middle Neolithic of the North European Plain [w:] Origins and Spread of Domestic Animals in Southwest Asia and Europe, red. S. Colledge, J. Conolly, K. Dobney, K. Manning, S. Shennan, London.

Nadolna M.

2001 Osada ludności kultury ceramiki wstęgowej rytej na stanowisku Miechowice 7, [maszynopis pracy magisterskiej, Biblioteka Instytutu Prahistorii UAM] Poznań.

Orschiedt J., Haidle M.N.

2006 The LBK Enclosure at Herxheim: Theatre of War or Ritual Centre? References from Osteoarchaeological Investigations, Journal of Conflict Archaeology 2/1, s. 153-167.

Pyzel J.

2010 Historia osadnictwa społeczności kultury ceramiki wstęgowej rytej na Kujawach, Gdańsk.

Russell N.

2002 The wild side of animal domestication, Society and Animals 10/ 3, s. 285-302.

Schibler J., Jacomet S.

2010 Short climatic fluctuations and their impact on human economies and societies: The potential of the Neolithic lake shore settlements in the Alpine foreland, Environmental Archaeology 15/2, s. 173-182.

Schmitt D.N., Lupo K.

2008 Do faunal remains reflect socioeconomic status? An ethnoarchaeological study among Central African farmers in the northern Congo Basin, Journal of Anthropological Archaeology 27, s. 315-325.

Schwartz-Mackensen G.

1983 Die Siedlung der ältesten Linienbandkeramik von Eitzum, Ldkr. Wolfenbüttel [w:] Frühe Bauernkulturen in Niedersachsen, red. G. Wegner, Oldenburg, s. 23-36. 


\section{Szmyt M.}

1992 Łojewo, gm. Inowrocław, woj. bydgoskie, stan. 35, osiedle z fazy wczesnowióreckiej kultury pucharów lejkowatych (Z badań nad genezą i systematyką kultury pucharów lejkowatych na Kujawach), Sprawozdania Archeologiczne 44, s. 49-98.

Vanmontfort B.

2008 Forager-farmer connections in an "unoccupied" land: First contact on the western edge of LBK territory, Journal of Anthropological Archaeology 27, s. 149-160.

Wiślański T.

1969 Podstawy gospodarcze plemion neolitycznych w Polsce pótnocno-zachodniej, Wrocław.

Wyrost P.

1994 Dawna fauna Polski w świetle badań kostnych materiałów archeologicznych. Rozmieszczenie w czasie i przestrzeni, Roczniki Akademii Rolniczej w Poznaniu 259/19, s. $75-176$.

\section{ECONOMIC AND SOCIAL IMPORTANCE OF NON-DOMESTICATED ANIMALS TO THE EARLY-NEOLITHIC COMMUNITIES IN CENTRAL EUROPE}

\section{S u m m a r y}

The purpose of this article has been to recognize the role and importance of non-domesticated animals in the early Neolithic of Central Europe. For this purpose, there have been selected three regions of settlement, representative for the area: the Elbe and Saale river basin, Małopolska and Kujawy, where the greatest number of sites discussed herein was recorded. There were fourteen sites analysed for the presence of non-domesticated animal bones, and analysed remains from selected sites of the Linear Pottery culture (Eilsleben, Samborzec, Miechowice 7, Łojewo 35, Bożejewice 22/23, Żegotki 2, Tübingen 4, Smólsk 4 , Zagajewice 1, Wolica Nowa 1, Siniarzewo 1) and the late Linear Pottery Culture (Żegotki 3, Kuczkowo 5, Węgierce 12, Radojewice 29, Siniarzewo 1), located in the selected regions.

The following variables have been taken into consideration: the percentage of non-domesticated taxa (compared to domestic ones), their species and anatomical composition. Also a contextual analysis has been carried out in order to identify co-occurrence of wild animal bones with other categories of artefacts and their spatial distribution at a site. Species of domestic animals have been treated here as a part of the context. Sites and settlement areas were then compared with each other in two aspects - space and time, and they were recognised as representing an earlier or later phase. The aim has been to capture, how the importance of wild fauna had changed in space with time elapsed since the beginning of colonisation of early farmers. The article has been based mainly on the available literature, in particular the published data.

For the purpose of the analysis the database was created, containing: name of a site, features within a site containing the remains of wild fauna (and, as far as the information was available, the function they served), detailed data on the remains of domesticated animals and, if possible, artefacts from features. Later, information on species and anatomical composition of non-domesticated animals has been included into the database. 
The results of the analysis carried out in the selected settlement areas in Central Europe were then compared with other regions of early Linear Pottery settlement in Central Europe. The analysis was done in two aspects - economic, where special emphasis was placed on environmental factors, and social, where issues such as the identity of the group, contacts with Mesolithic people, and food taboos were dealt with. The results clearly indicate that hunting was an important area of the economy of the first farmers inhabiting Central Europe. The most popular game were species such as red deer (Cervus elaphus), roe deer (Capreolus capreolus) and wild boar (Sus scrofa). The data obtained from the sites (distribution of anatomical parts, cut marks on the bones) has helped to recognise consumer-like approach towards hunting. In the article emphasis has been placed on the complexity of this issue.

Translated by Lucyna Leśniak 